\title{
Standardization of servuction processes as a competitiveness strategy in micro service companies in the city of Tehuacan
}

\section{Estandarización de los procesos de servucción como estrategia de competitividad en empresas de microservicios en la ciudad de Tehuacán}

\author{
MASCARÚA-ALCÁZAR, Miguel Antonio*†, JUÁREZ-PÉREZ, Sagrario, AGUILAR-SORIANO \\ Cinthya del Carmen and ROSAS-TRINIDAD, María Antonieta Guadalupe
}

Universidad Tecnológica de Tehuacán

ID $1^{\text {st }}$ Author: Miguel Antonio, Mascarúa- Alcázar / CVU CONACYT ID: 241576

ID $1^{\text {st }}$ Coauthor: Sagrario, Juárez- Pérez

ID $2^{\text {nd }}$ Coauthor: Cinthya del Carmen, Aguilar- Soriano / CVU CONACYT ID: 441481

ID $3^{\text {rd }}$ Coauthor: María Antonieta, Rosas-Trinidad / CVU CONACYT ID: 442049

DOI: $10.35429 / J B D S .2019 .16 .5 .12 .26$

Received June 15, 2019; Accepted December 30, 2019

\section{Abstract}

This chapter details, within the framework of competitiveness in the state of Puebla, a methodological proposal for the standardization of the processes of servuction of the MSE of the tourism sector, in an area of influence located in the region of Tehuacán - San Diego Chalma. The objective was to provide tools to MSEs so that they can generate strategies aimed at standardizing their processes, through a general methodology that consisted of: a) Defining the objective of the MSME in terms of profitability, b) Characterizing the service, c) Characterizing the client, d) Characterizing its process, e) Making the diagnostic summary and f) Making the decision making process. Once the execution of the proposed methodology has been completed, the SME will be able to identify the integral services it wishes to standardize based on observation, repetition and measurement in order to propose adjustments in the times that will speed up its procedures and thus standardize the production of its services. Finally, it is concluded with the premise that, if a more significant number of SMEs are formed in the understanding of servuction processes, this could lead to the growth of competitiveness in the tourism sector of the city of Tehuacán since competition becomes more orderly and focused on the specific values of each MSE.

Servuction, Competitiveness, Standardization and MSE

\section{Resumen}

Este capítulo detalla, en el marco de la competitividad en el estado de Puebla, una propuesta metodológica para la estandarización de los procesos de servucción de la MSE del sector turístico, en un área de influencia ubicada en la región de Tehuacán - San Diego Chalma. El objetivo era proporcionar herramientas a las MIPYMES para que puedan generar estrategias destinadas a estandarizar sus procesos, a través de una metodología general que consistía en: a) Definir el objetivo de la MIPYME en términos de rentabilidad, b) Caracterizar el servicio, c) Caracterizar el cliente, d) Caracterizar su proceso, e) Hacer el resumen de diagnóstico yf) Hacer el proceso de toma de decisiones. Una vez que se haya completado la ejecución de la metodología propuesta, la PYME podrá identificar los servicios integrales que desea estandarizar en función de la observación, la repetición y la medición para proponer ajustes en los tiempos que acelerarán sus procedimientos $\mathrm{y}$, por lo tanto, estandarizará producción de sus servicios. Finalmente, se concluye con la premisa de que, si se forma un número más significativo de PYME en la comprensión de los procesos de servucción, esto podría conducir al crecimiento de la competitividad en el sector turístico de la ciudad de Tehuacán, ya que la competencia se vuelve más ordenada y enfocada en los valores específicos de cada MSE.

Servucción, Competitividad, Estandarización y MSE

Citation: MASCARÚA-ALCÁZAR, Miguel Antonio, JUÁREZ-PÉREZ, Sagrario, AGUILAR-SORIANO Cinthya del Carmen and ROSAS-TRINIDAD, María Antonieta Guadalupe. Standardization of servuction processes as a competitiveness strategy in micro service companies in the city of Tehuacan. Journal of Business Development Strategies. 2019, 5-16: 12-26

\footnotetext{
* Correspondence to Author (email: miguel.mascarua@uttehuacan.edu.mx)

$\dagger$ Researcher contributing first author.
} 


\section{Introduction}

Although large companies have had significant growth, both in terms of turnover and in terms of expanding structures and diversifying markets and products, small and micro enterprises have survived with limited markets and significant shortages to stimulate their growth. Micro and small enterprises (MSEs) in Mexico are essential because of the volume of consumption of finished products and employment that is marginal but important for society. However, they have significant disadvantages because they are immersed in markets of exaggerated competition, and this fact has led them to experience low income and, in some cases, indifferent behavior with the different audiences that consume their goods or services. In a city where industrial activity has not been the point of sustained and stable economic growth in the long term, this paper seeks to delve into the tourism sector.

Competitiveness is also a situation that MSEs are at a disadvantage since they do not have systems that allow for a flow of knowledge to grow in the establishment of business goals and objectives. This lack of knowledge about demand and the resulting lack of sales can be solved when the entrepreneur acts with a different organizational attitude, through customer service processes in a sequential and organized manner, so that the process of servuction leads to the MSE to experience growth by having better way to compete in the market, regularly rotate an inventory, and meet customer needs.

\section{Literature revision}

\section{Competitiveness}

For Jones \& Teece, competitiveness is the relationship between domestic production and market opening and competitiveness with opening. In the words of Kotler and Armstrong (2012), the way to make companies competitive is when superior performance is achieved not only in product management activities (see Figure 1), but also in management activities with customers. The generation of value to achieve competitive performance against competitors

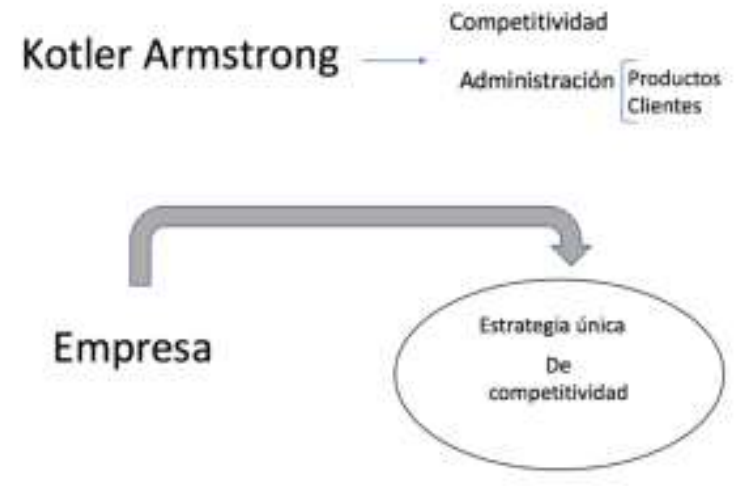

Figure 1

Source: Prepared by the authors, 2017

The intention is to analyze the competition and recognize those who, as competitors, are not a danger to the company, as those who are. However, a common strategy for all companies does not exist, so each company must make its competitiveness strategy.

Other approaches to competitiveness situate it as a macroeconomic tool with application in the sectoral and regional spheres (See Figure 2), as pointed out by Blanco's studies. This idea is taken up again by Fagerberg, who mentions that competitiveness is an economic policy objective, and it is here that Krugman's criticisms become a reality where the main countries have allocated government funds in order to potentialize the different economic sectors.

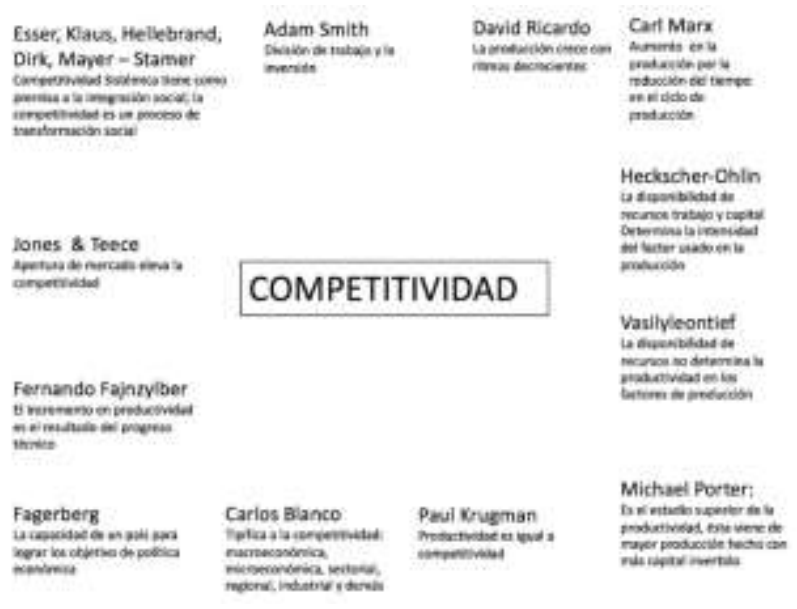

Figure 2

Source: Gracia, 2008 
The theoretical model of comparative advantage remained as a support for productivity until Porter (2015) demonstrated that competitiveness is a superior state to productivity since production is achieved with a higher level of profitability through the creation of value chains arising from creative innovation.

\section{Production}

When capitalism was established as the predominant mode of production, the object of study was supply and with it the way to make production grow. Productivity took its place after D. Ricardo criticized A. Smith's statements about increasing production through the division of labor and capital investment (Smith, 2014).

Critical approaches have stated that countries' productivity is associated with elements such as education, support for MSEs, and other types of support. However, some argue that productivity is the result of the same economic conditions in the relationship between countries. Fajnzylber argues that the relationship exhibited by modern nations is one of economic and technological dependence.

This dependence is materialized by the relationship of the nations that have more income and that identify themselves as center nations, while the nations with less income are the peripheral nations. Productivity is supported by technical progress, and for this purpose, the external sector has to be developed in order to raise domestic income. This defines the relationship of dependence of some nations on others and how competitiveness schemes are built (Gracia, 2008).

\section{Servuction}

The way people live has changed worldwide. More services have been created to meet new demands, and it is a fact that $70 \%$ of the world's Gross National Product (GNP) is service-related, and more than $60 \%$ of the world's workforce is employed in this sector. In the case of Mexico, approximately $55 \%$ of the population is employed in this sector. Therefore, the management of services is now important (Lara, 2002). The services have distinctive characteristics such as intangibility, heterogeneity, simultaneity between production and consumption, and not durability. The combination of people and material elements is what gives rise to servuction.
The servuction process offers the service you want to give and specifically to whom will be given the infrastructure and human capital that allows the proper functioning of the system and the subsystems of the management of organizations to achieve the quality to design a creative process in order to make the company different and achieve its survival in the competition within the market (Lopez \& Ruiz, 2011).

For some authors, the servuction process is a quality process that tends towards excellence (See Figure 3). The quality must obey the uniformity in the specifications, must be perceived by the customer because he perceives the value of the service, which implies that the organization must have its system and a value system determined by the objectives of management.

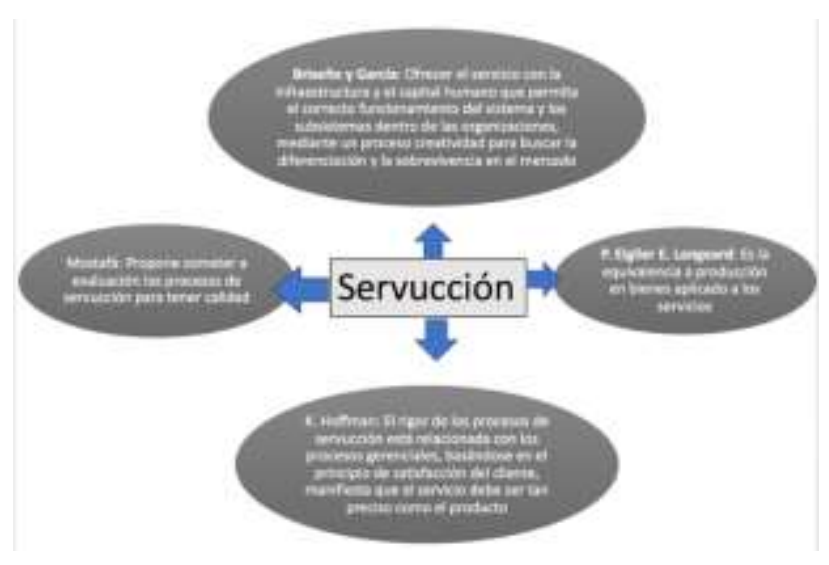

Figure 3

Source: Briseño and García, 2008

The servuction process makes an essential difference between the production of a good and a service since both require defined processes. However, in the service production process, an important element is the client (Briceño \& Garcia, 2008).

Román (2012) emphasizes that the concept of servuction provides a particular vision of business management (See Figure 4). This emphasizes the manufacture of the service because it commits to quality in a system that consists of a). The client; b). The physical support; c). The contact personnel and d). The service. 


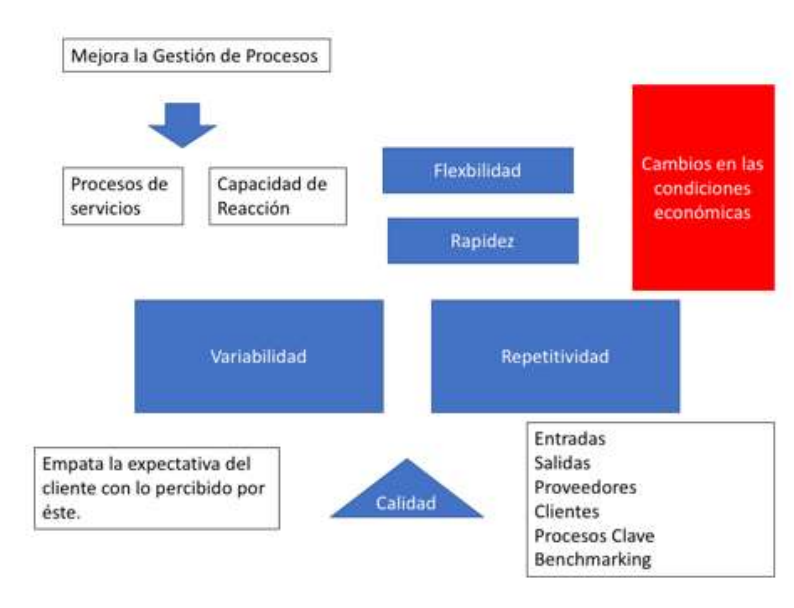

Figure 4

Source: Prepared by the authors with information from Hernández, Nogueira, et al., 2013

Recently, servuction has been the object of analysis since a quality service process involves activities such as the basic transport of people, specialized services such as medicine. In any of them it is required to create quality process management (See Figure 5).

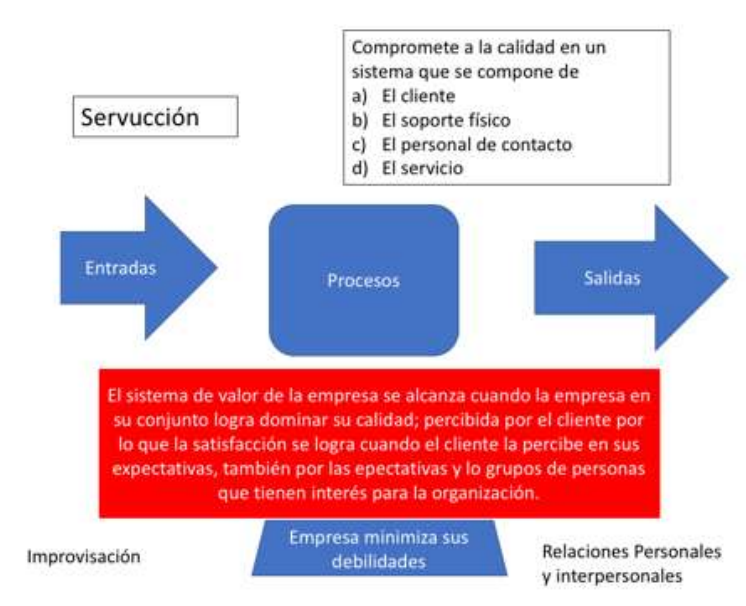

Figure 5

Source: Prepared by the authors with information from Román, 2012

The company's value system is achieved when the company as a whole manages to master quality. Therefore, the company must resolve the antagonism between the expected service and the perceived service. This is achieved when the organization minimizes its weaknesses, such as improvisation and intrapersonal and interpersonal relationships. Thus, servuction can be measured by 1 . effectiveness with expectations, 2. experience with the products of competitors, and 3. feedback from third parties (Briceño \& Garcia, 2008).
In the case of micro and small enterprises, the production of services is the most critical activity due to its low investment cost and its versatility in facing rapid changes in demand and its essential contribution to job creation.

\section{Marketing}

\section{Recognition of the use of marketing}

It is about knowing that the recognition of entrepreneurs for using marketing applied to their businesses is not a priority issue. To make a comparison, we present the results of surveys applied in the health sector, 55\% of a sample of 908 professionals answered yes, compared to $45 \%$ who said they were against the effectiveness of the use of marketing in their work units and business.

Besides, in the modality of acquisition of marketing knowledge, 20\% said they learned in a conference; $18 \%$ self-taught, another $18 \%$ learned by attending courses and $15 \%$ learned through a subject in their master's studies (Suarez, Hernandez, Cajan, Remoaldo, Torres, $\&$ Priego, 2016).

Another important point is the reason for using marketing, where the answers that correspond to the utility in the area of specialty, for the case of Mexico, was the most chosen answer; however, the answers about increasing the efficiency and effectiveness of the work, obtaining easy results, taking into account the user and development of skills were the least chosen answers.

\section{Behavior in response to competitive marketing}

According to Ramaswamy's writings, competitive marketing behavior expresses a situation of business rivalry that is manifested by the use of market strategies, and the focus is on the type of actions that a company takes to face the competition. Three types of behavior can be identified: vindictive, cooperative, and grassroots (Vera \& Itriago, 2008). Retaliatory behavior, which is the behavior that a company exhibits, is vindictive because the actions of an organization go in the same direction as the competitor, that is, if the competitor lowers prices, the competing company will do the same, as well as increasing efforts in sales expenses, the competitor will execute the same actions. 
Cooperative behavior is a behavior in which companies do not consider the actions of the competition to be aggressive, and the company's reaction is to maintain the competitive position. This behavior occurs in oligopolistic markets. Baseline behavior is what is used to have a different basis when a company increases its marketing efforts, and the competitor reduces them.

Competitive behavior is based on the study of the relationship of variables such as market growth, market concentration, standardization, the difference in costs of the leading competitor compared to the costs of the competitors, the positioning differential (relative perception of the business unit manager about the company's image, as well as the related services) and the type of product.

As far as small enterprises are concerned, the use of marketing reduces its use to the decisions of business owners (GutiérrezLeefmans \& Nava-Rogel, 2016) as far as the micro-environment of the company is concerned, while in the macro-environment it determines how the entrepreneur defines the strategy and structure of the business.

Based on the writings of Kotler and Armstrong, marketing is a social and managerial process where companies and individuals get what they need, and this allows them to exchange value with others. Marketing also evolves as a result of technological advances, so context is fundamental to making marketing practice more focused and supported by scientific analysis of data.

\section{Means-End Chain}

The Means-end Chains model was developed by the University of New Hampshire academic Jonathan Gutman in 1982. The tool is based on the knowledge that the consumer has about a product or service, creating a chain based on the link between the attributes of the product $(\mathrm{A})$, the consequences of its use (C) and the personal values that are considered satisfied by the consumer (V). According to Lazzati (2015), the advantages of the means-end chain are
- $\quad$ It helps to link a goal at a certain level with a goal at a higher level. In this way, the vision is broadened, and the solution of problems tends to contribute to the achievement of the organization's fundamental objectives.

- It stimulates the development of alternatives.

- It helps to transform general objectives into specific achievable actions.

It highlights the interrelations that need to be considered.

- $\quad$ It helps to delimit the information that should be gathered and helps to provide a system for the organization.

- The limitations of the means-end chain are:

The chain itself does not involve the evaluation of objectives or alternatives, although it can help to this end

- $\quad$ The link with higher-level objectives tends to be complicated by the existence of contradictory objectives.

Figure 6 shows an example of the model applied in decision making.

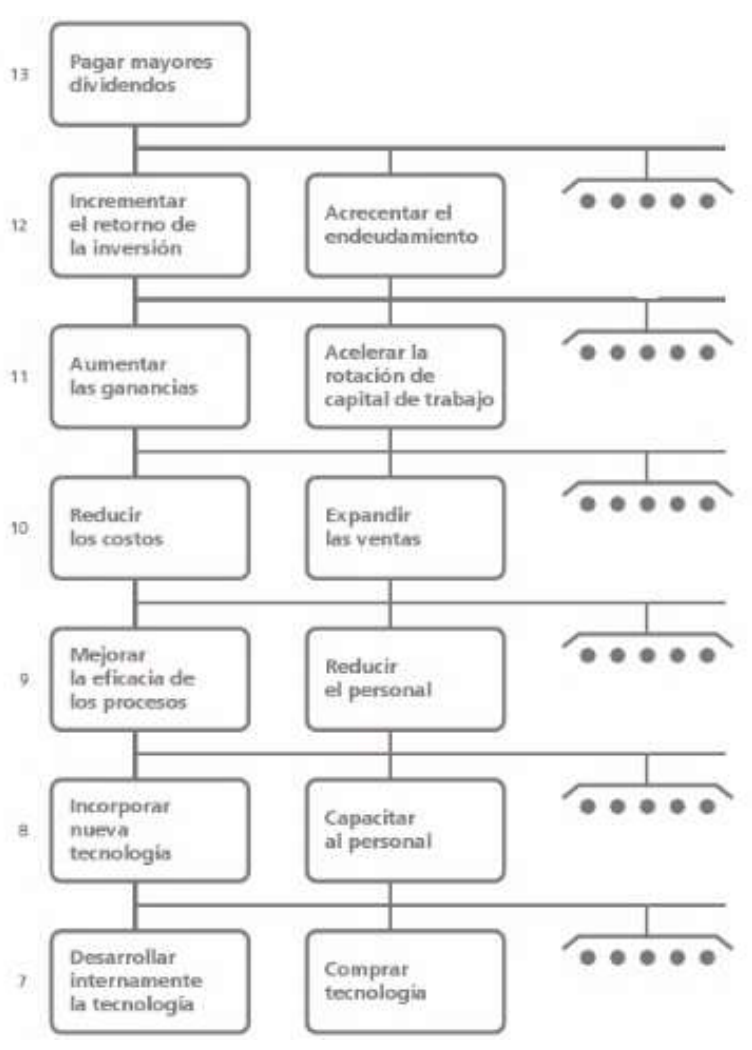

Figure 6

Source: Lazatti, 2013 


\section{Strategic planning}

Strategic planning is aimed at reducing the organization's inefficiencies because it allows for better customer service, under the resources, particularities of the markets where the company operates, and establishes a correspondence between the company or organization and the economic objectives of the authorities (Betancourt \& Barreiro, 2005). Of the factors identified for success such as (a) knowledge of the market; (b) planning of purchase and merchandise; (c) capacity to react; (d) efficiency and motivation of human resources; (e) image; (f) location and (g) the skills required, for this work particular attention is paid to point (c), which consists of the diagnosis of customer needs; knowledge of customer satisfaction; systems for planning and commercial control; certainty and speed in administrative management and financial capacity. These variables allow for framing the actions that denote a response to industrial competition in the market where the organizations operate.

More structured models suggest a relationship between the impact of market strategy and profits (Mosqueda \& Montaudon, 2011). Econometric models reinforce the empirical validity of the Impact of Market Strategy on Profits (PIMS) model, for this, the model is reinforced with the PBC model of Phillips, Chang, and Buzzelli that relates the structure of the strategic management with the costs of the company, the market share, the relative prices of the products, the return of the investment, the variables under control, the quality and a margin of error. ${ }^{1}$

\section{Working methods and systems}

\section{Measurement of work}

Work measurement is a method based on research into various techniques to determine the content of a defined task by determining the time a skilled worker spends on carrying it out according to a pre-determined performance standard. The objectives that are satisfied with time measurement are

To increase the efficiency of the worker. To provide time standards that will inform other systems in the company, such as the cost of production scheduling, supervision, etc.

\section{Development of the study of times and relationship with the simplification of work}

If we examine the analytical process he followed, we find:

1. The analysis of all operations in order to eliminate those that were unnecessary.

2. The determination of the best method of execution.

3. The standardization of methods, materials, tools, equipment and working conditions.

4. The exact determination of the time a qualified operator needs to execute a job.

In order to simplify the work, an analysis of the work can be made, which leads to the following conclusions:

\footnotetext{
- $\quad$ Eliminate all unnecessary work.

- Combine the operations or their elements.

Change the sequence of operations

- $\quad$ Simplify the operations.
}

\footnotetext{
${ }^{1}$ The model PBC $=\mathrm{f}\left(\mathrm{C}_{\mathrm{it}}, \mathrm{MS}_{\mathrm{it}}, \mathrm{P}_{\mathrm{it}}, \mathrm{ROI}_{\mathrm{it}}, \mathrm{QUA}_{\mathrm{it}}, \mathrm{CV}_{\mathrm{it}}, \varepsilon_{\mathrm{it}}\right)$. Where $\mathrm{C}$ is the company's costs, MS is the market share, $\mathrm{P}$ is the relative prices of the products, ROI is the return on investment, QUA is the quality, CV is the variables under control and $E$ is the model error. In the PIMS model, the analysis of the variables of market share and return on investment were taken with special importance, since these allowed to establish the model of Competitive Strategy of the PIMS that is composed of the marketing strategy and competitive management, which affect the results of permanence, cash flow, growth, value added and share price.
} 
As an aid to carry out this analysis, as well as to simplify the method, several diagrams are available, such as those of the operation process, flow process, the operator and his machine, course diagram, and the bimanual. When the detailed study of each one of these diagrams is appropriate, during the study of the method, a brief note will be taken with the service providers, the method used will be studied. After analyzing it, an improved method will be proposed, using comparative tables that indicate the advantages obtained, the codifications that have been made to the method, and the increase of the efficiency (García, 1969).

\section{Application of work measurement}

In order to more easily understand the purpose and applications of job measurement in industry, the following definitions are given below:

Work measurement: It is the quantitative part of the study of work that indicates the result of the physical effort developed as a function of the time allowed to an operator to finish a specific task, following a predetermined method at an average pace.

Standard time: It is the pattern that measures the time required to finish a unit of work, through the use of a method, by a worker who has the required skill, who develops an average speed that he can maintain day after day, without showing symptoms of fatigue.

Applications of standard time: Currently, there are multiple applications of standard time, among which are the following:

1. To determine the salary of the person responsible for that specific task.

2. To support production planning.

3. To know more accurately the amount of services that can be produced.

4. To help establish workloads.

5. To help formulate a standard costing system.

6. To provide cost estimates based on standard labor times

7. To provide a solid foundation for establishing incentive systems and their control.

8. To help train new workers.

\section{Work measurement techniques}

The main techniques used to measure work are as follows:

$-\quad$ By estimation of historical data
$-\quad$ Timing study with stopwatch
$-\quad$ By decomposition into micro movements
of predetermined times Methods Time
(MTM), Modular Organization of
Predetermined Standard Times
(MODAPTS), Maynard Operation
Sequence Techinque (MOST) technique
Method of the instantaneous
observations (work sampling).
Standard data and time formulas.

\section{Time study preparation}

Selection of the operation. To begin with, it is necessary to determine which operation is to be measured. Its timing, in the first order, is a decision that depends on the overall objective pursued by the measurement study. However, the following criteria can be used to make the choice:

The order of the operations as they are presented in the process

The possibility of savings expected in the operation, related to the annual cost of the operation as calculated by the equation:

- $\quad$ Annual cost of the operation= (Annual activity) (Time of operation) (Hourly wage) (Galvan, 1980)

\section{Time measurement}

Once all the general information has been recorded, the next phase consists of measuring the time of the operation, a task called timing.

\section{Analytical courses}

An analytical course diagram is the graphic representation of the order of all operations, transports, inspections, delays and storages that take place during a process or procedure, and comprises the information considered suitable for analysis, such as: time required and distance travelled (See Table 1). 


\begin{tabular}{|l|l|}
$\begin{array}{l}\text { Symbols } \\
\text { used in } \\
\text { courses }\end{array}$ & Description of the symbols \\
\hline & $\begin{array}{l}\text { An operation represents the main stages of } \\
\text { the process. Something is created, changed } \\
\text { or added. Operations involve activities such } \\
\text { as cutting and dismantling something. }\end{array}$ \\
\hline $\begin{array}{l}\text { Inspection occurs when units in the } \\
\text { production system are checked, verified, } \\
\text { revised, or examined for quality and/or } \\
\text { quantity. }\end{array}$ \\
\hline $\begin{array}{l}\text { Transport is the movement of personal or } \\
\text { study object material from one position or } \\
\text { situation to another. }\end{array}$ \\
\hline $\begin{array}{l}\text { Delay occurs when conditions do not allow } \\
\text { or require immediate execution of the next } \\
\text { planned action. }\end{array}$ \\
\hline $\begin{array}{l}\text { Storage occurs when something remains at } \\
\text { a site without being worked on or in the } \\
\text { process of being worked on, waiting for an } \\
\text { action at a later date. }\end{array}$ \\
\hline
\end{tabular}

Table 1 Course symbology

Source: Industrial engineering online, 2017

With the graphic representation of the facts we get an overview of what is happening, and we understand more easily both the facts themselves and their relationship to each other.

\section{Contextual framework}

\section{Business activity in the State of Puebla}

In the State of Puebla, business activity faces significant challenges in achieving sales in a market scenario that mostly operates in exacerbated competition and conditions of legal and operational uncertainty; Such is the case of the City of Tehuacán, Puebla, where the lack of competitiveness of MSEs is observed among microentrepreneurs who have stated that the lack of sales, to achieve sustained economic growth, is one of the most critical problems, according to Mascarúa, Juárez et al. (2016). However, it is also evident their lack of interest in investing in actions that allow them to know their demand.

A common problem of the companies that operate businesses in Puebla has to do with the recognition of the use of marketing as an axis generating competitive advantages to stand out against the competition in the industrial sector. To this, it is interesting that in spite of the recognition of the advantages that the use of marketing offers, there are businessmen that do not hire specialized consultancy services. Therefore, there is not a generation of marketing strategies that translates into an entirely measurable result.
This explains that the use of marketing is not always executed with an objective to promote the sustainability of businesses in the long term, in many cases, the use of marketing is due to simple reasoning without specific objectives to apply the strategies to establish a price according to the needs of demand, the choice of the place is not always located in areas of higher profitability. Therefore, marketing strategies are not always created on a scientific basis.

\section{Elements of the tourist activity in Ciudad del Sol located in San Diego Chalma}

Tourism activity has a place in the tertiary sector (Boullón, 2006). It is neither a science nor an industry, but rather the consequence of a social phenomenon that arises from the existence of free time and the development of transport systems (See Figure 7).

\section{Funcionamiento del sistema turistico}

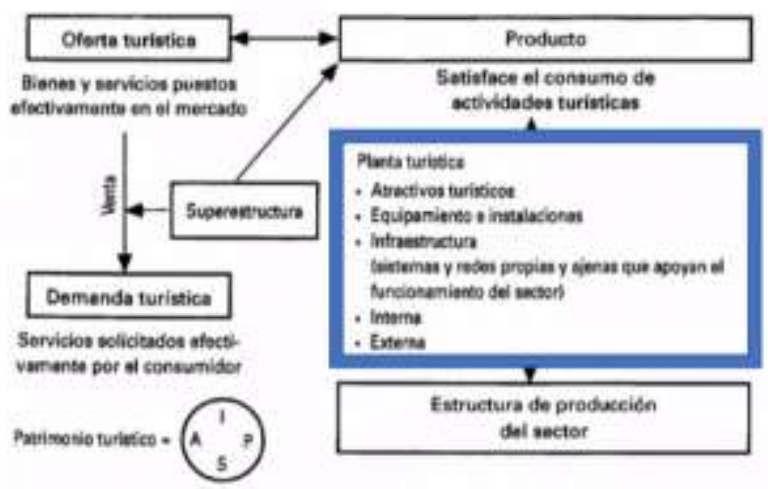

Figure 7

Source: R. Boullón, 2006

For this work, the servuction processes of the equipment will be analyzed (See Figure 8), but not of the facilities, and only of those existing in Tehuacán that in turn are directly related to the influx of tourism to the recently inaugurated Ciudad del Sol.

The tourist plant includes all the services that allow tourist activity such as Accommodation, Food, Leisure and other services, according to Boullon's classification, some of which are not found in the Mexican market or allude to other types of services. 


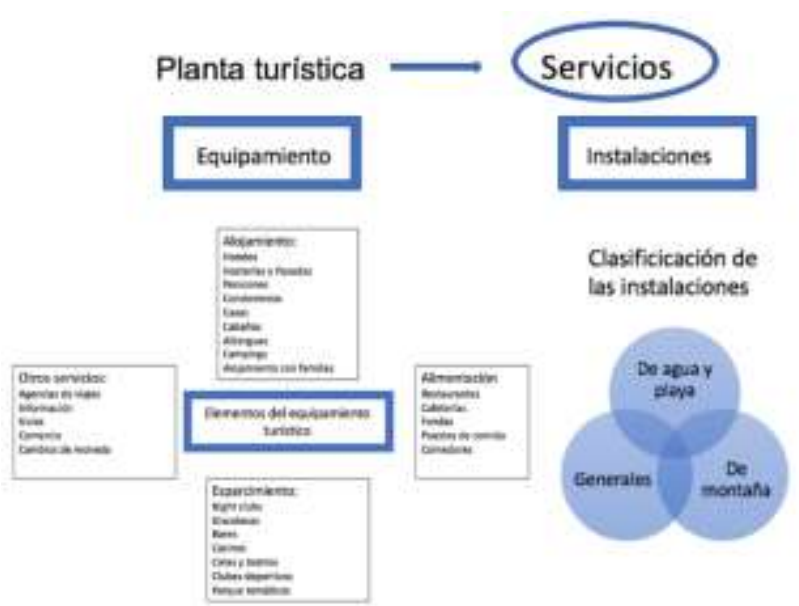

Figure 8

Source: Prepared by the authors with information from Boullón, 2006

\section{Stratification of tourist MSMEs on the Tehuacán-San Diego Chalma route}

In 2017, according to Boullón's classification of the equipment of the tourist activity (Figure 8), in the region of Tehuacán-San Diego Chalma there are 215 MSMEs registered with the Secretary of Tourism of Tehuacán (dependent on SEDECO), of the tourist sector which are shown in Figure 9.
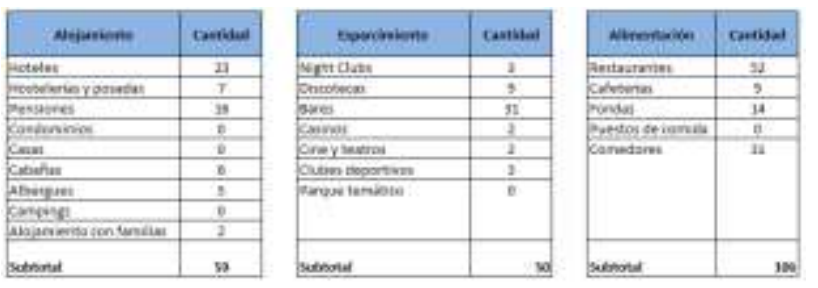

\section{Figure 9}

Source: Prepared by the authors with information from Secretaria de Turismo de Tehuacán, 2017

The percentage participation of greater impact with $49 \%$ belongs to the food category, as shown in Figure 10, so this analysis proposes to focus on the standardization of servuction in the food tourism sector.

\section{ESTRATIFICACIÓN DE MYPES}

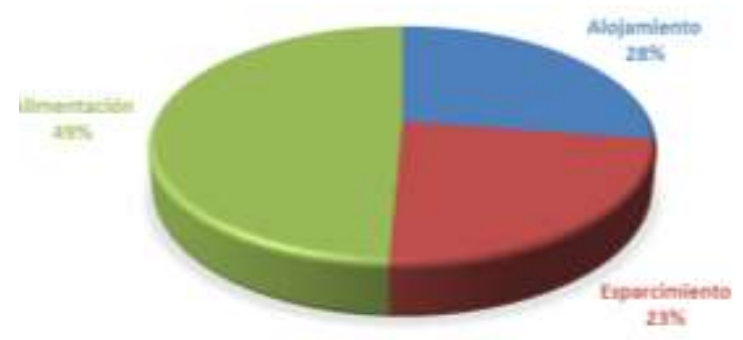

Figure 10

Source: Prepared by the authors with information from Secretaria de Turismo de Tehuacán, 2017

\section{Methodological proposal for the standardization of servuction in MSEs of the tourism sector Foods of the Tehuacán-San Diego Chalma, Puebla route}

In the event that established MSEs seek to maintain or increase their profitability in the short term in a competitive framework with their counterparts, they must:

1. Define the objective in terms of profitability

2. Characterize the Service

3. Characterize the Client

4. Characterize the Process

5. Performing the diagnostic summary

6. Carrying out the decision-making process

\section{Defining the objective in terms of profitability}

Profitability is the percentage relationship that exists between the benefits provided by the operation of the main service and the monetary investment that was exercised. The MSE must answer the following questions, in order to identify the areas of opportunity to improve in the short term.

1. What is your net profit per day?

2. Would you like to increase the profit margin and by what percentage?

3. In how much time do you want to reach the desired increase?

4. Would you be willing to improve your current situation?

5. Do you know your current resource capacity (economic, human, time)?

If the answer to question 4 is positive, proceed with the characterization of the service.

\section{Characterization of the service}

A service is an intangible asset that is produced and consumed at the same time, achieving a variable result that depends on who provides it, when and where. To perform the service characterization, first all the integrated services linked to the main service must be identified, for example: 


\section{- Service:}

Food Integrated services:

Time of attention (order-delivery)

Product presentation

Hygiene of the establishment

Playground or play area

Health services

Cafeteria Services

Etc.

Subsequently, for each integrated service (detached from its main service), Table 3 should be filled in as shown in column three, where the integrated service was chosen for time of service, in order to analyze the factors that make up the main service and their direct impact on the profitability of the MSE.

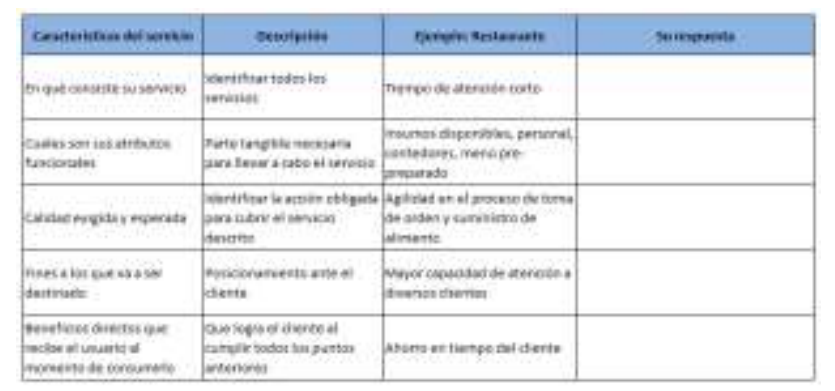

Table 3 Service characterization

Source: Own elaboration, 2017

At the end of the characterization of all its services, the MSE will have identified those integrated services that bring greater benefits to its clients in order to improve them.

\section{Characterization of the client}

The Customer is an entity that uses (consumes and pays for) a service on a regular basis, so the MSE should characterize its main customers and potential customers under the following questions.

1. What days do I offer my service?

2. What are my business hours?

3. What kind of specific needs does my service satisfy?

4. What kind of customers can pay for my service?

5. What is the age range of my customers?

6. What is the added value my customers perceive?
The answers to the questions as a whole will give a general description of the type of customer who regularly buys the services. Therefore, the characterization of the service and the customer will allow to focus on the measurable processes that make up the main service.

\section{Characterization of the process}

Process: These are the operations (acts-actions) carried out to execute a service. Of the integrated services identified in section 5.2, the MSE should select those services that are quantifiable in terms of time to execute a methodology of methods and system of work in order to standardize the time of their processes. For example, the following times are included in the study of service time:

Time of attention in the order-taking

Food processing time

Food delivery time

Main service charging time

The MSE must execute the subroutine proposed below to measure the integrated service of interest.

1. Record a video of the process to provide the integrated service of interest

2. Identify in the video the operations that make up the integrated service and list them in the DESCRIPTION column (See Figure 11)

3. Mark the type of activity to which each described operation corresponds (See figure 11)

4. Take the time in seconds involved in each operation described

5. Repeat steps 1 to 4 for 10 cycles.

6. Calculate the average time of each operation and write it down in the Time column

7. Draw the operation route of the marked activities (See Figure 11)

8. Fill in the Format Summary section with the calculation of the current times and establish the desired times in the Proposed section (See figure 11) 


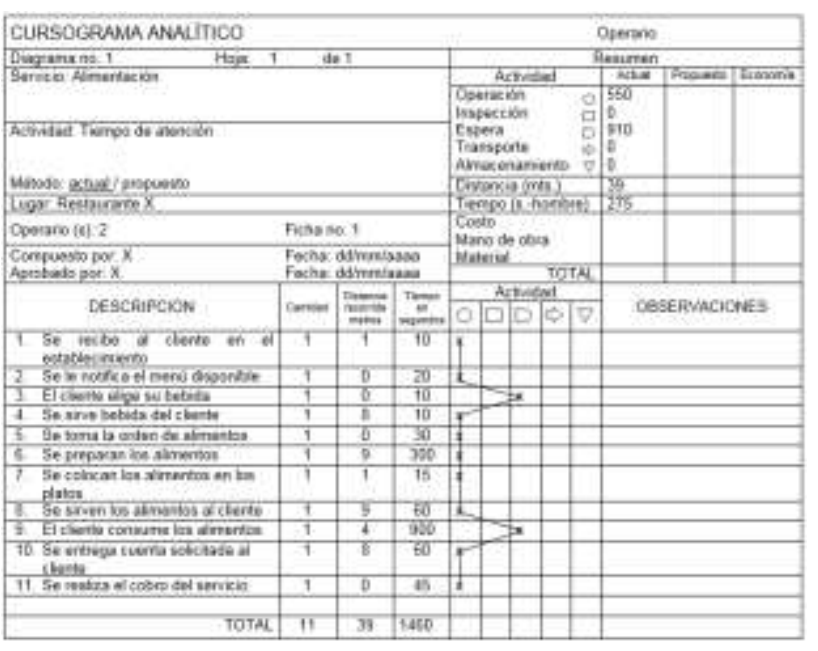

Figure 11

Source: Prepared by the authors, 2017

Distinguishing each of the operations with their respective times will allow the owner of the MSE to size the times incurred by individual operations and also generate a proposal of desired times.

\section{Performing the diagnostic summary}

The purpose of this step is to integrate the information collected into the development of the proposed methodology (5.1. to 5.4.) to generate a diagnostic summary that describes the following phases:

Phase 1. Determine the financial information: how much utility I currently generate, how much utility I want to generate, in what time I want to generate it, and the availability to make an investment for the standardization of the service.

Phase 2. Determine and prioritize the integrated services that make up the main service. With this, the MSME will focus its efforts on the factor that could generate a competitive advantage.

Phase 3. Describe the client type of MSE to encourage their permanence.

Phase 4. Identify the integrated service or services to be standardized from having observed, repeated and measured in order to propose adjustments to time to streamline their procedures and standardize the production of their services.

\section{Carrying out the decision-making process}

From the diagnostic summary, the MSE identifies the particular objective it wants to attack, which is oriented to cover the general objective of establishing strategies to achieve the standardization of their servuction processes, for this purpose it is proposed the use of a technique for decision making called means-end chain (See Figure 12).

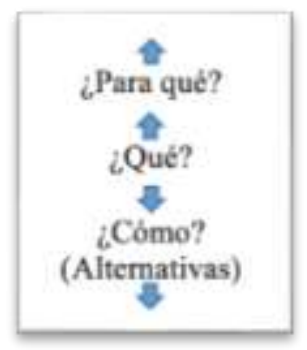

Figure 12

Source: Lazatti, 2013

Gutman's means-chain is useful to focus on the problem, clarify objectives, and generate alternatives.

Taking the example of Lazzati (2015) that exposes the problem: the costs are too high, which is expressable in terms of a goal: to reduce costs. Two questions are then posed, a) Why do we want to reduce costs? and b) How can costs be reduced? the answers could be:

- $\quad$ (WHY) To increase profits

- (HOW) Improve the efficiency of the servuction process

The respective answers to WHAT and HOW are reformulated, leading to the identification of higher and lower level objectives, respectively. Continuing with the examples:

a) Why increase profits) and b) How can the efficiency of the productive/servicing processes be improved; the new answers could be

(WHY) To increase the return on investment

(HOW TO) Perform the servuction processes in less time 
The process can be repeated, and the MSE decides where the analysis cuts off, i.e., how many times to ask why and how until it finds the route of action to be followed and what actions to take. The means-end chain of the example developed is shown in Figure 13.

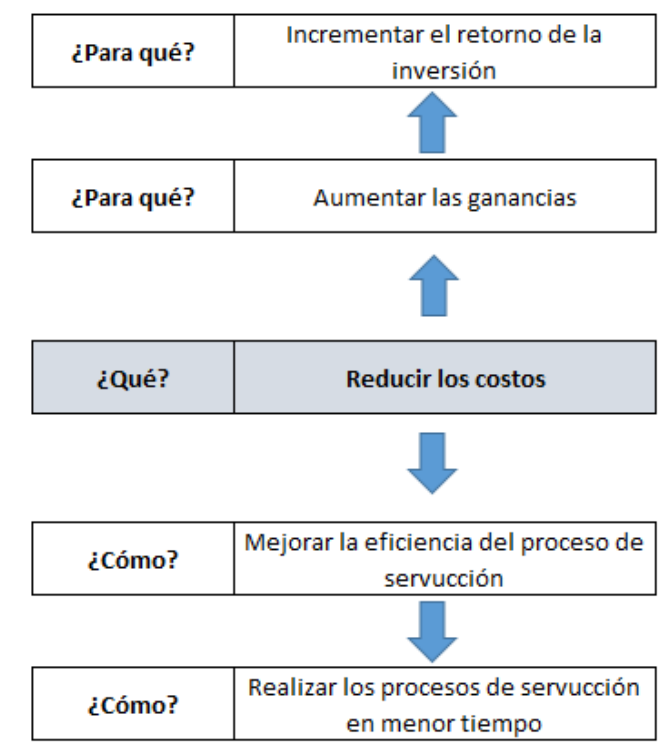

\section{Figure 13}

Source: Prepared by the authors with information from Lazatti, 2017

In conclusion, the higher level objectives (what for) will be those that represent the deep motivations of MSEs, while the lower level objectives (how) will represent the means to be satisfied to achieve the desired goal or state.

\section{Conclusions}

Throughout the work, we exposed the need to support the growth of MSEs as a trigger strategy for economic development. Many authors have already pointed out the importance of the sector. The new economic policies have led to see the tourism sector as an essential reason to consolidate regional growth, hence the way to achieve self-criticism schemes by MSEs is essential for their long-term sustainability.

Servuction processes make sense when MSEs achieve their standardization to react adequately to competition while fostering competitive and competitive markets. Training could help small entrepreneurs to know their market better, to know the needs of the customers who visit them, to generate productivity strategies in inventory management, product innovation, better business infrastructure, and better management of relationships with suppliers, competitors, authorities, and customers.

Vázquez \& Labarca (2012) state that those companies that create standardization processes, achieve more effectively the certification of their processes, which allow better monitoring and control of operations to consolidate the quality of products and services based on customer satisfaction. An improvement in the processes allows better competitiveness of the company and its suppliers.

We have presented a proposal for measuring activity times that arise from the entrepreneur's self-knowledge, the knowledge of their resources, and the knowledge of their consumers' needs. The tools shown here will allow the MSEs of the Tehuacán-San Diego Chalma service corridor to explore their resource management and an approach with certainty to their service market.

\section{References}

Chacholiades, M. (1988). Economía Internacional. Mexico: McGraw-Hill.

Chaffey, D., \& Smith, P. (2013). Emarketing excellence. Planning and optimizing your digital marketing. New York: Routledge.

Lara, J. R. (April, 2002). La gestión de la calidad de los servicios. Recuperado el 30 de Enero de 2017, de Redalyc/Ecest: http://www.bibliotecaecest.mx/busqueda

Castañón, J. L. (Dec. 10, 2014). Globalización, ciencia y tecnología. Recovered on September 22, 2016, from Competitividad y sistemas de innovación

http://infoandina.mtnforum.org/sites/default/file s/publication/files/85.Competitividad_y_sistem as_de_innovaci_n_los_retos_para_la_inserci_n _de_M_xico_en_el_contexto_global.pdf

Lazzati, S. (2015). La toma de decisiones: Principios, procesos y aplicaciones. Buenos Aires: Granica.

Lecuona, R. (1999). Algunos rasgos de la transición mexicna a la economía global. En E. Vilatela, \& Bancomext (Ed.), México, transición económica y comercio exterior (Segunda ed., pág. 482). Mexico: F.C.E. 
Lopez, A., \& Ruiz, L. M. (May 20, 2011). La servucción como proceso de creación del servicio. Caso del Hotel Tuxpan. Recovered on January 2017, from Gestiopolis: http://www.gestiopolis.com/la-servuccioncomo-proceso-de-creacion-del-servicio/

López, L. M., \& Calderón, G. (2006). ANÁLISIS DE LAS DINÁMICAS CULTURALES AL INTERIOR DE UN CLÚSTER EMPRESARIAL. Estudios gerenciales, 3- 15.

Betancourt, C. d., \& Barreiro, L. A. (Noviembre de 2005). Experiencias en la planiricación estratégica de marketing en una unidad de comercio minorista de bienes en divisas. Obtained from Info Trac. Gale Group: http://go.galegroup.com/ps/i.do?p=IFME\&u=pu $\& \mathrm{id}=\mathrm{GALE} \mid \mathrm{A} 170113049 \& \mathrm{v}=2.1 \& \mathrm{it}=\mathrm{r} \& \mathrm{sid}=\mathrm{su}$ mmon\&userGroup=pu\&authCount $=1$

BID. (Nov. 12, 2002). Banco Interamericano de Desarrollo. División de Micro, Pequeña y Mediana Empresa. Recovered on September 24, 2016, from Guía operativa para programas de competitividad para la pequeña y mediana empresa.:

http://www.redmicrofinanzas.cl/index_files/333 21 guiaopyme.pdf

Bielschowsky, R. (April, 2009). Sesenta años de la CEPAL: estructualismo y neoestructuralismo. Revista CEPAL(97), 173 - 194.

Boullón, R. C. (2006). Planificación del Espacio Turístico (Vol. 1). México, CDMX, Mexico: Trillas.

Briceño, M. Y., \& Garcia, O. (Feb. 16, 2008). La servucción y la calidad en la fabricación del servicio. Recovered on January 23, 2017, from Conricyt:

http://www.saber.ula.ve/bitstream/123456789/2 5181/2/articulo2.pdf

García, M. L. (April 18, 2012). Pensamiento y gestión. Recovered on August 25, 2016, from Una propuesta para la determinación de la competitividad en la pyme latinoamericana: http://www.scielo.org.co/scielo.php?script=sci arttext\&pid=S1657-62762012000200005
Gracia, M. (December, 2008). Los determinantes de la competitividad nacional. Análisis y reflexiones a partir de un nuevo marco teórico conceptual. Recovered on January 27, 2017, from Universidad del Mar: http://www.utm.mx/edi_anteriores/temas036/E NSAYO2-36.pdf

Gutiérrez-Leefmans, C., \& Nava-Rogel, R. M. (Jan.-April, 2016). Mercadotecnia digital y las pequeñas y medianas empresas: revisión de la literatura. Obtained from Revista Venezolana de información, tecnología y conocimiento: http://www.redalyc.org/articulo.oa?id=8234601 6004

Gutman, J. (Sept., 1997). Means-end chains as goal hierarchies. Psychology and Marketing, 14(6), 545-560.

Hall, B. H., \& Kahn, B. (May, 2003). Adoption of new technology. Obtained from NBER: http://www.nber.org/papers/w9730

Hernandez, A., Nogueira, D., Medina, A., \& Marques, M. (Oct.-Dec., 2013). Inserción de la gestión por procesos en instituciones hospitalarias. Concepción metodológica y practica. Recovered on January 30, 2017, from Info Trac/ Gale Group: http://gs3sr3zm5k.search.serialssolutions.com/? ctx_ver=Z39.88-

2004\&ctx_enc=info\%3Aofi\%2Fenc\%3AUTF$8 \&$ rfr_id=info $\% 3$ Asid $\% 2$ Fsummon.serialssoluti ons.com\&rft_val_fmt=info $\% 3$ Aofi $\% 2 \mathrm{Ffmt} \% 3$ Akev\%3Amtx\%3Ajournal\&rft.genre=article \& $\mathrm{r}$ ft.atitle=Inserción+de+la+gestión+por+proceso s+en+instituciones+hospitalarias.+Concepción+ metodológica $+y+$ práctica\&rft.jtitle $=$ Revista + de + Administração\&rft.au=Arialys + Hernández $+\mathrm{N}$ ariño\&rft.au $=$ Dianelys + Nogueira + Rivera\&rft.a $\mathrm{u}=$ Alberto+Medina+León\&rft.au=Maylin+Mar qués+León\&rft.date=2013-10-

$01 \&$ rft.pub=Universidade+de+São+Paulo\%2C+ FEA+-

+ Departamento+de+Administração\&rft.issn=00 80-2107\&rft.eissn $=1984$ -

$6142 \&$ rft.volume $=48 \&$ rft.issue $=4 \&$ rft. spage $=7$ 39\&rft.externalDocID=3328386911\&paramdict $=$ es-ES

Herra, S. A. (May, 1999). El mercadeo como instrumento estratégico en las empresas de servicios. Obtained from Info Trac. Gale Group: http://go.galegroup.com/ps/i.do?p=IFME\&u=pu $\& \mathrm{id}=\mathrm{GALE} \mid \mathrm{A} 139908898 \& \mathrm{v}=2.1 \& \mathrm{it}=\mathrm{r} \& \mathrm{sid}=\mathrm{su}$ mmon\&userGroup $=$ pu\&authCount $=1$

MASCARÚA-ALCÁZAR, Miguel Antonio, JUÁREZ-PÉREZ, Sagrario, AGUILAR-SORIANO Cinthya del Carmen and ROSASTRINIDAD, María Antonieta Guadalupe. Standardization of servuction processes as a competitiveness strategy in micro service companies in the city of Tehuacan. Journal of Business Development Strategies. 2019 
Instituto Mexicano para la Competitividad. (Nov., 2015). Recovered on September 8, 2016, from La corrupción en México: tranzamos y no avanzamos:

http://imco.org.mx/indices/\#!/competitividad_in ternacional_2015/introduccion

Instituto Mexicano para la Competitividad A. $C$. (2015). Recovered on September 8, 2016, from Índice de Competitividad Internacional 2015: http://imco.org.mx/indices/\#!/competitividad_in ternacional_2015/resultados/subindice/derecho

Instituto Nacional del Emprendedor. (2015). Recovered on September 8, 2016, from Construccion, generacion y Análisis de Indicadores para medir el Ecosistema Emprendedor Mexico: http://www.mx.undp.org/content/dam/mexico/d ocs/Publicaciones/PublicacionesReduccionPobr eza/one/ConstrucciongeneracionyAnalisisdeInd icadoresparamedirEcosistemaEmprendedorMex ico.pdf

Kotler, P., \& Armstrong, G. (2012). Marketing (14th ed.). (M. Contreras, Ed., \& L. E. Pineda, Trad.) Mexico: Pearson.

Krugman, P. (April, 1994). Competitividad: una peligrosa obsesión. Recovered on January 27, 2017, from Foreign Affairs: https://www.foreignaffairs.com/articles/199403-01/competitiveness-dangerous-obsession

Malthus, R. T. (1826). Ensayo sobre el principio de la población (Sexta ed., Vol. 1). (J. Murray, Ed.) London.

Marx, K. (2014). El capital. Critica de la Economía Política (Tercera ed., Vol. 2). (W. Roces, Trad.) Mexico.

Marx, K. (2014). El capital. Crítica de la economía política (Tercera ed., Vol. 1). (J. Dewey, Ed., \& W. Roces, Trad.) Mexico: F.C.E.

Mascarua, M. A., Juarez, S., Rodriguez, C., \& Hernandez, J. C. (2016). El estrés y su impacto en la productividad: estudio de los directivos de las micro ypequeñas empresas de Altepexi, Miahuatlán y Tehuacán. En O. C. Aguilar, R. Posada, N. B. Peña, \& S. Fonseca (Ed.), El estrés y su impacto en la productividad. Estudio en los directivos de las micro y pequeñas empresas en México. (Vol. 1, pág. 592). Mexico, Mexico: Pearson Educación.
Mosqueda, R. M., \& Montaudon, C. (MayAugust, 2011). Challenges and perspectives in using PIMS methodology to explain the succes of the marketing strategy in Business. Obtained from

Scielo:

http://www.scielo.org.mx/scielo.php?script=sci _arttext\&pid=S0186-

10422011000200005\&lng=es\&nrm=iso\&tlng= en

Nicholson, W., \& Snyder, C. (2015). Teoría microeconómica. Principios básicos y aplicaciones (11th ed.). (A. Vega, Ed., E. Mercado, \& J. A. Valdes, Trads.) Mexico: Cengage.

Niebel, B. W., \& Freivalds, A. (2009). Ingeniería industrial: métodos, estándares y diseño del trabajo (12th ed.). (R. A. Del Bosque, Ed., C. R. Cordero, \& J. E. Murrieta, Trads.) Mexico: Mc Graw-Hill.

OCDE. (June 5, 2004). Promoting entrepreneurship and innovative SME's in a global economy. Retrieved February 10, 2017, from

OCDE:

https://www.oecd.org/cfe/smes/31919590.pdf

OCDE. (2010).

Ochoa, H., \& Ríos, A. M. (Oct.-Dec., 2011). Liderazgo, la competencia esencial que trasformó una empresa colombiana en un gigante internacional: el caso de Cementos Argos. Obtained from Info Trac. Gale Group: http://go.galegroup.com/ps/i.do?p=IFME\&u=pu $\& \mathrm{id}=\mathrm{GALE} \mid \mathrm{A} 301870292 \& \mathrm{v}=2.1 \& \mathrm{it}=\mathrm{r} \& \mathrm{sid}=\mathrm{su}$ mmon\&userGroup=pu\&authCount=1

Ochoa, H., Ríos, A. M., \& Solano, N. (AprilJune, 2011). La innovación como competencia central en la internacionalización de las firmas latinoamericanas: el proceso de Bico Internacional, empresa del Grupo Carvajal S.A. Obtained from Info Trac. Gale Group: http://go.galegroup.com/ps/i.do?p=IFME\&u=pu \&id=GALE $\mid$ A302114065\&v=2.1\&it=r\&sid=su mmon\&userGroup $=$ pu

Padilla, D. N. (2008). Contabilidad Administrativa. Mexico: Mc GrawHill/Interamericana Editores S.A.

Porter, M. (2015). Ventaja competitiva. Mexico: Grupo Editorial Patria. 
Portillo, R., \& Pirela, J. (2009). El mercadeo social/estratégico de los productos/servicios y la definición del perfil de competencias del profesional de la información. Obtained from Info Trac. Gale Group: http://go.galegroup.com/ps/i.do?p=IFME\&u=pu $\& \mathrm{id}=\mathrm{GALE} \mid \mathrm{A} 236570058 \& \mathrm{v}=2.1 \& \mathrm{it}=\mathrm{r} \& \mathrm{sid}=\mathrm{su}$ mmon\&userGroup $=\mathrm{pu}$

R., D. C. (January-June, 2008). Redalyc.org. Recovered on September 11, 2016, from La competitividad a reisión: caso México: http://www.redalyc.org/articulo.oa? $\mathrm{id}=2570160$ 4

Render, B., \& Heizer, J. (2014). Principios de administración de operaciones (Novena ed.). (P. De la Vega, Ed., \& J. E. Murrieta, Trad.) Naucalpan de Juárez, Mexico: Pearson educación.

Reyes, M., \& Reyes, O. (January-June,e 2012). Las necesidades de capacitación de empresarios de Mipymes del valle de Mexicali, méxico y la demanda de capacitación de los mismos, en el semestre 2011-1. Obtained from Info Trac de Gale Group/Conricyt: http://go.galegroup.com/ps/i.do?p=IFME\&u=pu $\& \mathrm{id}=\mathrm{GALE} \mid \mathrm{A} 369063401 \& \mathrm{v}=2.1 \& \mathrm{it}=\mathrm{r} \& \mathrm{sid}=\mathrm{su}$ mmon\&userGroup=pu\&authCount $=1$

Ricardo, D. (2014). Principios de Economía Política y Tributación (2nd ed.). (P. Sraffa, M. H. Dobb, Edits., J. Broc, N. Wolff, J. Estrada, \& M. Sanchez, Trads.) Mexico: F.C.E.

Rincón, C. A. (2011). Presupuestos empresariales. Bogotá: Ecoe Ediciones.

Roman, A. (Feb., 2012). Quality servuction. Recovered on January 30, 2017, from MedWave

http://www.bibliotecaecest.mx/busqueda

Smith, A. (2014). Una investigación sobre la naturaleza y causas de la riqueza de las naciones (Primera en Español ed.). (E. Cannan, Ed., \& G. Franco, Trad.) Mexico: F.C.E.

Suárez, N., Hernández, C., Caján, M., Remoaldo, P. C., Torres, C., \& Priego, H. R. (2016). Conocimientos y actitudes hacia la mercadotecnia en salud en paises de Iberoamerica. Obtained from Revista cubana de salud pública: http://www.redalyc.org/articulo.oa?id=2144493 1012
Vazquez, C., \& Labarca, N. (Diciembre de 2012). Calidad y estandarización como estrategias competitivas en el sector agroalimentario. Recovered on February 2, 2017, from Redalyc: http://www.redalyc.org/articulo.oa?id=2902489 2002

Vera, J., \& Itriago, M. (January-April, 2008). Determinando comportamiento competitivo de mercadotecnia. Una revisión crítica para planteamientos a futuro. Obtained from Contaduría y administración.: www.redalyc.org/articulo.oa?=39512459005

Zevallos, E. V. (June 11, 2006). Obstaculos de desarrollo en las pequeñas y medianas empresas en America Latina. Recovered on September 13, 2016, from FUNDACIÓN PARA EL DESARROLLO SOSTENIBLE: file:///C:/Users/pc/Downloads/186-188-1PB.pdf
MASCARÚA-ALCÁZAR, Miguel Antonio, JUÁREZ-PÉREZ, Sagrario, AGUILAR-SORIANO Cinthya del Carmen and ROSASTRINIDAD, María Antonieta Guadalupe. Standardization of servuction processes as a competitiveness strategy in micro service companies in the city of Tehuacan. Journal of Business Development Strategies. 2019 